\title{
VITAMIN D STATUS IN RENAL TRANSPLANT RECIPIENTS IS NOT ASSOCIATED WITH ERECTILE DYSFUNCTION
}

\author{
Bojan Sudarević1,2, Ivana Begići, ${ }^{3,4}$, Dalibor Šimunović ${ }^{1,2}$, Hrvoje Kuveždić1,2, \\ Vatroslav Šerić ${ }^{5,2}$ and Lada Zibar ${ }^{3,6}$
}

${ }^{1}$ Department of Urology, Osijek University Hospital Center; ${ }^{2}$ School of Medicine, Josip Juraj Strossmayer

University of Osijek; ${ }^{3}$ Department of Dialysis, Clinical Department of Internal Medicine, Osijek University Hospital Center; ${ }^{4}$ Department of Physiology and Immunology, School of Medicine, Josip Juraj Strossmayer University of Osijek; ${ }^{5}$ Department of Clinical Laboratory Diagnosis, Osijek University Hospital Center; ${ }^{6}$ Department of Pathophysiology, School of Medicine, Josip Juraj Strossmayer University of Osijek, Osijek, Croatia

SUMMARY - Erectile dysfunction (ED) is a highly prevalent disorder among renal transplant recipients. Vitamin D deficiency (VDD) has been associated with several ED risk factors but only recently directly linked to $\mathrm{ED}$. We conducted a study to investigate whether vitamin D serum levels were associated with the presence and severity of ED in 40 male patients that underwent deceased donor kidney transplantation (TX) from 2001 to 2013. Blood samples were collected on two seasonally distinct occasions and $25(\mathrm{OH}) \mathrm{D}$ concentration was assessed by radioimmunoassay. A 5 -item version of the International Index of Erectile Function (IIEF-5) was used for ED evaluation and group stratification. We found comparable rates of ED (75\%) and VDD (42.5\%-62.5\%) as in previously published studies. Serum levels of $25(\mathrm{OH}) \mathrm{D}$ did not differ between patients with and those without $\mathrm{ED}$ on both measurements ( $\mathrm{p}=0.656$ and $\mathrm{p}=0.914$, respectively), or when comparing different ED severity groups. Duration of renal replacement therapy before TX and graft duration until analysis were longer in patients with $\mathrm{ED}(\mathrm{p}=0.022$ and $\mathrm{p}=0.05$, respectively), but with the results being nonsignificant on logistic regression. In conclusion, we found no association of $25(\mathrm{OH}) \mathrm{D}$ concentration with the presence and severity of ED in renal transplant recipients. So far, there are no similar published data.

Key words: Vitamin D deficiency; Erectile dysfunction; Endothelium, vascular; Renal insufficiency, chronic; Kidney transplantation; Croatia

\section{Introduction}

Erectile dysfunction (ED) is defined as persistent inability of a man to achieve and/or maintain penile erection sufficient for sexual activity. It is a highly prevalent disorder worldwide, with the reported prevalence of $69.2 \%$ of men, varying according to different

Correspondence to: Assoc. Prof. Lada Zibar, MD, PhD, Department of Dialysis, Clinical Department of Internal Medicine, Osijek University Hospital Center, Josipa Huttlera 4, HR-31000 Osijek, Croatia

E-mail: ladazibar@gmail.com

Received July 14, 2016, accepted October 31, 2016 methodological approaches in the published studies, and increasing with age $\mathrm{e}^{1-3}$. ED was historically considered a benign condition, however, not only does it impair the quality of life but also carries an increased risk of impending cardiovascular disease (CVD) ${ }^{4}$ because of the common pathological mechanism of endothelial dysfunction (END).

Vitamin D has recently been shown to have a wide variety of extraskeletal effects, with pathways linked to cancer, autoimmune disorders and CVD. By changing the expression of 200 to 2000 genes that have vitamin $\mathrm{D}$ response elements, these effects include inhibition of angiogenesis and cellular proliferation, stimulation 
of apoptosis and terminal differentiation ${ }^{5}$. A randomized, double-blind study ${ }^{6}$ has revealed that vitamin D supplementation indeed changed the expression of genes linked to CVD, which have been associated with vitamin D deficiency (VDD). VDD is defined as serum circulating 25-hydroxyvitamin $\mathrm{D}(25(\mathrm{OH}) \mathrm{D})$ concentration below $20 \mathrm{ng} / \mathrm{mL}$, vitamin $\mathrm{D}$ insufficiency as $25(\mathrm{OH}) \mathrm{D}$ of $21-29 \mathrm{ng} / \mathrm{mL}$, and sufficiency above $30 \mathrm{ng} / \mathrm{mL}^{7}$.

Vitamin D deficiency has previously been associated with several ED risk factors such as hypertension, diabetes mellitus (DM) and atherosclerosis, which all cause endothelial impairment of penile vasculature, as well as with some nonvascular disorders linked both to $\mathrm{ED}$ and $\mathrm{VDD}^{8}$. One recent study ${ }^{9}$ found a direct link between the presence of ED and VDD.

The prevalence of ED in chronic kidney disease (CKD) patients is reported to be about $80 \%{ }^{10}$, which is higher than in general population. Albeit the etiology of $\mathrm{ED}$ is usually multifactorial, there are numerous CKD specific factors that predispose these patients to ED, including hormonal abnormalities, END, comorbidities, polypragmasy, and depression. There are no recent or conclusive data on VDD and ED in CKD population, but a report ${ }^{11}$ from 1977 implied that treatment with vitamin $\mathrm{D}$ supplements reduced $\mathrm{ED}$ severity in dialysis patients. In a setting after renal transplantation (TX), erectile function seems to improve compared to pre-transplant dialysis period ${ }^{10}$, although ED remains frequent companion of renal transplant recipients. There are recent efforts in focusing not only on patient and graft survival but also on the life quality after renal TX, where ED plays an important role ${ }^{12}$.

Since data on VDD and ED in CKD population are sparse, in this study we set to determine vitamin D status of renal transplant recipients on two seasonally distinct measurements and to investigate whether vitamin D serum levels are associated with the presence and severity of ED. To our knowledge, there are no similar data published so far.

\section{Patients and Methods}

The study was conducted at the Department of Urology and Department of Dialysis, Osijek University Hospital Center, where transplant recipients have their regular checkup. The study was approved by the
Ethics Committee of the Osijek University Hospital Center, in accordance with the 2000 Declaration of Helsinki and 2008 Declaration of Istanbul. After having obtained their written informed consent, 40 male patients having undergone deceased donor kidney TX from 2001 to 2013 were enrolled in the study. Patient characteristics were obtained by an in-house questionnaire, while clinical data were collected from patient charts and medical records. Blood samples were collected from cubital vein on two seasonally distinct occasions: first sample in summer 2013 (June through August) and second sample in winter 2013/2014 (December through April), with body height and weight measurements taken during physical examination on both occasions.

Assessment of vitamin D serum concentration was performed with DIAsource radioimmunoassay and immunoradiometric assay kit was used for parathyroid hormone (PTH) measurement (DIAsource ImmunoAssays S.A., Louvain-la-Neuve, Belgium), following the manufacturer's instructions.

A simplified 5-item version of the International Index of Erectile Function (IIEF-5) was used as a diagnostic tool for ED evaluation ${ }^{13}$ and to further divide study subjects into different ED categories. According to the IIEF-5 score, the patients were categorized as no $\mathrm{ED}$ (ED 0; score 22-25), ED 1 (score 17-21), ED 2 (score 12-16), ED 3 (score 8-11) and ED 4 group (score $\leq 7)$. The groups were then compared according to serum levels of $25(\mathrm{OH}) \mathrm{D}$, complete blood count, hemoglobin, PTH, fasting blood glucose, creatinine, high-sensitivity $\mathrm{C}$-reactive protein (hs-CRP), cholesterol and triglycerides per body mass index (BMI), duration of renal replacement therapy (RRT) before TX, and kidney graft duration until analysis.

Statistical analysis was performed with the SPSS statistical program (version 15.0, SPSS Inc., Chicago, IL, USA). All data were reported as median (range from minimum to maximum), unless noted otherwise. Difference between two independent samples was calculated with Mann-Whitney test, and among more than two independent samples with Kruskal-Wallis test, while Mann-Whitney test was used for post-hoc analysis. Wilcoxon signed-rank test was used for related samples and Fisher exact test for categorical data. Correlations were assessed using Kendall's $\tau$-B coefficient and multivariate analysis with Hosmer-Lemeshow test. A two-sided $\mathrm{p}$-value of $<0.05$ was considered statistically significant. 


\section{Results}

Demographic characteristics of 40 study participants having undergone kidney TX from June 2001 to May 2013 are shown in Table 1. Glomerulonephritis was the primary cause of end-stage renal disease (ESRD) in most of the subjects and $90 \%$ of the pa-

Table 1. Demographic characteristics of study population $(N=40)$

\begin{tabular}{|l|l|}
\hline & $\mathrm{n}(\%)$ \\
\hline Primary cause of ESRD & $19(47.5)$ \\
Glomerulonephritis & $8(20)$ \\
Interstitial nephritis & $6(15)$ \\
DM & $5(12.5)$ \\
ADPKD & $2(5)$ \\
Arterial hypertension & \\
\hline Immunosuppressive therapy & $20(50)$ \\
TAC-based & $13(32.5)$ \\
CsA-based & $7(17.5)$ \\
mTOR-inhibitor-based & \\
\hline TX No. & $36(90)$ \\
$1^{\text {st }}$ & $2(5)$ \\
$2^{\text {nd }}$ & $2(5)$ \\
$3^{\text {rd }}$ & \\
\hline Comorbidities & $8(20)$ \\
DM & $4(10)$ \\
Angina pectoris/AMI & $4(10)$ \\
PAD & $0(0)$ \\
CVI & $34(85)$ \\
\hline Drugs & $26(65)$ \\
Antihypertensives & $25(62.5)$ \\
Statins & $23(57.5)$ \\
Beta blockers & $10(25)$ \\
ACE inhibitors/ARBs & $7(17.5)$ \\
Loop diuretics & $5(12.5)$ \\
Vitamin D supplements & $4(10)$ \\
Erythropoietin & \\
Bisphosphonates & \\
\hline & \\
\hline
\end{tabular}

$\mathrm{ESRD}=$ end-stage renal disease; $\mathrm{ADPKD}=$ autosomal dominant polycystic kidney disease; $\mathrm{TAC}=$ tacrolimus; $\mathrm{CsA}=$ cyclosporin; $\mathrm{mTOR}=$ mammalian target of rapamycin; $\mathrm{TX}=$ renal transplantation; $\mathrm{DM}=$ diabetes mellitus; $\mathrm{AMI}=$ acute myocardial infarction; $\mathrm{PAD}=$ peripheral arterial disease; $\mathrm{CVI}=$ cerebrovascular insult; $\mathrm{ACE}=$ angiotensin-converting enzyme; $\mathrm{ARBs}=$ angiotensin receptor blockers tients were first-time kidney transplant recipients. As expected, $77.5 \%$ of the patients were taking three or more drugs besides immunosuppressants, while seven patients received vitamin $\mathrm{D}$ supplements.

When stratified according to the IIEF- 5 score, ten patients had no ED (ED 0), 20 patients were classified as ED 1, seven patients as ED 2, and three patients as ED 4; there were no ED 3 patients. Median age of all patients was 52 (range 29-66) years, with no significant between-group difference $(\mathrm{p}=0.32)$. On the first (summer) measurement of $25(\mathrm{OH}) \mathrm{D}, 42.5 \%$ of $\mathrm{pa}-$ tients had VDD, 30\% were vitamin D insufficient, and $27.5 \%$ had sufficient levels of $25(\mathrm{OH}) \mathrm{D}$. On the second measurement (winter), 62.5\% had VDD, 17.5\% had insufficiency, and only $20 \%$ of patients were vitamin D sufficient. The levels of $25(\mathrm{OH}) \mathrm{D}$ did not differ between the two measurements $(p=0.737)$. There was no statistically significant between-group difference as compared according to serum levels of $25(\mathrm{OH}) \mathrm{D}$, PTH, hemoglobin, fasting blood glucose, creatinine, hs-CRP, cholesterol, triglycerides, BMI, duration of RRT before TX, and graft duration until analysis.

Then we compared the studied variables between patients without ED and those with any degree of ED (Table 2). Serum levels of 25(OH)D and other serum parameters analyzed yielded no statistically significant differences either. However, duration of RRT before TX and graft duration until analysis were shorter in ED 0 group ( $p=0.022$ and $p=0.05$, respectively). Logistic regression analysis of the two mentioned parameters plus age at the time of the study ( $p=0.083$ in univariate analysis) revealed no between-group difference $(\mathrm{p}=0.152, \mathrm{p}=0.479$ and $\mathrm{p}=0.334$, respectively).

When stratifying study subjects according to $25(\mathrm{OH}) \mathrm{D}$ cutoff of $20 \mathrm{ng} / \mathrm{mL}$ (Table 3), there was no difference in the IIEF-5 score, duration of RRT before TX and graft duration until analysis on either measurement. However, the first (summer) measurement showed lower HDL cholesterol, red blood cell and hemoglobin concentrations in VDD group ( $p=0.007$, $\mathrm{p}=0.013$ and $\mathrm{p}=0.009$, respectively). VDD group had lower HDL cholesterol on second (winter) measurement $(\mathrm{p}=0.016)$ again and higher PTH levels compared to non-VDD group ( $\mathrm{p}=0.009$ ). Logistic regression for the first measurement HDL, hemoglobin and serum glucose ( $p=0.097$ in univariate analysis) and for the second measurement HDL, hemoglobin ( $\mathrm{p}=0.065$ in univariate analysis) and PTH revealed the parame- 
Table 2. Comparison of non-ED (ED O) versus patients with any degree of ED (both summer and winter measurements)

\begin{tabular}{|c|c|c|c|}
\hline & ED 0 & ED 1-4 & $\mathrm{p}$-value \\
\hline $\mathrm{n}$ & 10 & 30 & \\
\hline Age (years) & $47.5(30-61)$ & $54(29-66)$ & 0.083 \\
\hline IIEF-5 score & $24.5(22-25)$ & $17(5-21)$ & $<0.001$ \\
\hline RRT before TX (months) & $21(9-95)$ & $47.5(8-108)$ & 0.022 \\
\hline $\begin{array}{l}\text { Graft duration until } \\
\text { analysis (months) }\end{array}$ & $20.5(5-81)$ & $35.5(1-145)$ & 0.05 \\
\hline BMI & $\begin{array}{l}25.45(22.7-31.1)^{\mathrm{A}} \\
26.35(22.7-31.1)\end{array}$ & $\begin{array}{l}25.15(21.5-37.8) \\
25.85(22.2-36.1)\end{array}$ & $\begin{array}{l}0.701 \\
0.914\end{array}$ \\
\hline $25(\mathrm{OH}) \mathrm{D}(\mathrm{ng} / \mathrm{mL})$ & $\begin{array}{l}20.99(6.22-59.62) \\
17.88(12.1-64.17)\end{array}$ & $\begin{array}{l}22.42(6.03-67.3) \\
19.86(3.4-42.3) \\
\end{array}$ & $\begin{array}{l}0.656 \\
0.914 \\
\end{array}$ \\
\hline $\operatorname{Hgb}(g / L)$ & $\begin{array}{l}139.5(103-151) \\
140.5(111-165)\end{array}$ & $\begin{array}{l}129(88-169) \\
135(80-164) \\
\end{array}$ & $\begin{array}{l}0.246 \\
0.656 \\
\end{array}$ \\
\hline Blood glucose (mmol/L) & \begin{tabular}{|l}
$5.7(4.8-7.2)$ \\
$5.45(5-6.2)$
\end{tabular} & $\begin{array}{l}5.4(3.7-19.7) \\
5.35(4.8-10.4)\end{array}$ & $\begin{array}{l}0.548 \\
0.678\end{array}$ \\
\hline Creatinine $(\mu \mathrm{mo} / \mathrm{L})$ & $\begin{array}{l}150(110-314) \\
135(102-223)\end{array}$ & $\begin{array}{l}128(80-483) \\
127.5(88-469)\end{array}$ & $\begin{array}{l}0.548 \\
0.842\end{array}$ \\
\hline hs-CRP (mg/L) & $\begin{array}{l}1.45(0.21-9.77) \\
2.395(0.41-13.62)\end{array}$ & \begin{tabular}{|l|}
$2.22(0.21-27.84)$ \\
$1.665(0.18-68.62)$
\end{tabular} & $\begin{array}{l}0.548 \\
0.286\end{array}$ \\
\hline Cholesterol (mmol/L) & $\begin{array}{l}4.94(3.6-7.8) \\
5.365(3.3-7.9)\end{array}$ & $\begin{array}{l}5.305(2.6-8.1) \\
5.53(2.6-8.5)\end{array}$ & $\begin{array}{l}0.522 \\
0.862\end{array}$ \\
\hline $\mathrm{HDL}(\mathrm{mmol} / \mathrm{L})$ & $\begin{array}{l}1.18(0.9-1.6) \\
1.275(0.9-1.5)\end{array}$ & $\begin{array}{l}1.15(0.8-2.6) \\
1.235(0.8-2.7)\end{array}$ & $\begin{array}{l}0.935 \\
0.528\end{array}$ \\
\hline $\mathrm{LDL}(\mathrm{mmol} / \mathrm{L})$ & $\begin{array}{l}3.2(2.1-5.5) \\
3.605(1.6-5.7)\end{array}$ & $\begin{array}{l}3.56(1.5-5.6) \\
4.205(1.6-5.9)\end{array}$ & $\begin{array}{l}0.706 \\
>0.99\end{array}$ \\
\hline Triglycerides (mmol/L) & $\begin{array}{l}2(1.1-6.3) \\
2.185(1.3-3.8)\end{array}$ & \begin{tabular}{|l|}
$1.88(0.7-7.3)$ \\
$1.63(0.9-7)$
\end{tabular} & $\begin{array}{l}0.544 \\
0.140\end{array}$ \\
\hline PTH $(\mathrm{pg} / \mathrm{mL})$ & $\begin{array}{l}120(33.9-442) \\
117.85(39.6-200)\end{array}$ & $\begin{array}{l}103.1(35.9-894) \\
60.3(13.6-735)\end{array}$ & $\begin{array}{l}0.469 \\
0.469\end{array}$ \\
\hline
\end{tabular}

All data reported as median (range from minimum to maximum); $\mathrm{p}$ calculated using Mann-Whitney test; ${ }^{A}$ upper value indicates summer and lower value winter measurement; ED = erectile dysfunction; IIEF-5 = International Index of Erectile Function questionnaire; RRT = renal replacement therapy; TX = renal transplantation; $\mathrm{BMI}=$ body mass index; $\mathrm{Hgb}=$ hemoglobin; hs-CRP = high-sensitivity C-reactive protein; HDL = high-density lipoprotein; $\mathrm{LDL}=$ low-density lipoprotein; $\mathrm{PTH}$ = parathyroid hormone

ters to pose no significant risk $(\mathrm{p}=0.06, \mathrm{p}=0.075$, $\mathrm{p}=0.141, \mathrm{p}=0.094, \mathrm{p}=0.363$ and $\mathrm{p}=0.059$, respectively). Oral vitamin D supplementation therapy had no impact on the distribution of $25(\mathrm{OH}) \mathrm{D}$ levels between the groups ( $\mathrm{p}=0.463$ and $\mathrm{p}=0.326$ for the first and second measurement, respectively).

\section{Discussion}

In the current study, we measured serum $25(\mathrm{OH}) \mathrm{D}$ concentration on two occasions in renal transplant recipients and found no association of vitamin $\mathrm{D}$ status with the presence and severity of ED. Along with the recent abundant evidence for extraskeletal effects of vitamin $\mathrm{D}$, there has been an increasing number of papers stressing its role in CVD, autoimmune and chronic inflammatory disorders, as well as in cancer. A review by Hossein-Nezhad and Holick ${ }^{5}$ emphasizes that a great deal of numerous vitamin $\mathrm{D}$ affected genes have a role in different tumor pathways, cellular cycle regulation and immuno-inflammatory modulation. 
Table 3. Comparison of 25(OH)D deficient versus non-deficient patients (both summer and winter measurements)

\begin{tabular}{|c|c|c|c|c|c|c|}
\hline & \multicolumn{3}{|c|}{ Summer measurement } & \multicolumn{3}{|c|}{ Winter measurement } \\
\hline $25(\mathrm{OH}) \mathrm{D}$ & $>20 \mathrm{ng} / \mathrm{mL}$ & $<20 \mathrm{ng} / \mathrm{mL}$ & $\mathrm{p}$ & $>20 \mathrm{ng} / \mathrm{mL}$ & $<20 \mathrm{ng} / \mathrm{mL}$ & $\mathrm{p}$ \\
\hline $\mathrm{n}$ & 23 & 17 & & 15 & 25 & \\
\hline Age (years) & $52(29-66)$ & $54(30-66)$ & 0.426 & $54(31-64)$ & $49(29-66)$ & 0.401 \\
\hline IIEF-5 score & $19(7-25)$ & $18(5-25)$ & 0.711 & $18(7-24)$ & $19(5-25)$ & 0.280 \\
\hline $\begin{array}{l}\text { RRT before TX } \\
\text { (months) }\end{array}$ & $48(8-105)$ & $29(9-108)$ & 0.194 & $46(8-103)$ & $44(9-108)$ & 0.748 \\
\hline $\begin{array}{l}\text { Graft duration } \\
\text { (months) }\end{array}$ & $33(1-145)$ & $22(4-106)$ & 0.298 & $28(1-145)$ & $34(4-137)$ & 0.716 \\
\hline BMI & $25(22.5-33.4)$ & $25.8(21.5-37.8)$ & 0.345 & $26.2(22.2-34)$ & $25.7(22.6-36.1)$ & 0.791 \\
\hline $25(\mathrm{OH}) \mathrm{D}(\mathrm{ng} / \mathrm{mL})$ & $29.49(20.71-67.3)$ & $9.11(6.03-20.27)$ & $<0.001$ & $35(21.35-64.17)$ & $16.2(3.4-20.3)$ & $<0.001$ \\
\hline $\mathrm{RBC}\left(\mathrm{x} 10^{12} / \mathrm{L}\right)$ & $4.9(3.44-6.19)$ & $4.11(3.26-5.04)$ & 0.013 & $5(4.17-6.71)$ & $4.65(2.89-6.2)$ & 0.083 \\
\hline $\operatorname{Hgb}(g / L)$ & $139(98-169)$ & $118(88-150)$ & 0.009 & $143(115-151)$ & $133(80-165)$ & 0.065 \\
\hline $\begin{array}{l}\text { Blood glucose } \\
(\mathrm{mmol} / \mathrm{L})\end{array}$ & $5.3(3.7-7.2)$ & $5.8(4.8-19.7)$ & 0.097 & $5.6(4.8-10.4)$ & $5.4(4.8-7.9)$ & 0.433 \\
\hline hs-CRP (mg/L) & $2.13(0.22-27.84)$ & $1.51(0.21-17.06)$ & 0.795 & $2.81(0.71-9.78)$ & $1.85(0.18-68.62)$ & 0.356 \\
\hline $\begin{array}{l}\text { Cholesterol } \\
(\mathrm{mmol} / \mathrm{L})\end{array}$ & $5.305(2.9-8.1)$ & $4.94(2.6-7.8)$ & 0.380 & $5.66(3.8-8.5)$ & $5.335(2.6-7.9)$ & 0.212 \\
\hline $\mathrm{HDL}(\mathrm{mmol} / \mathrm{L})$ & $1.39(0.8-2.6)$ & $1.09(0.8-1.5)$ & 0.007 & $1.45(0.9-2.7)$ & $1.16(0.8-1.9)$ & 0.016 \\
\hline $\mathrm{LDL}(\mathrm{mmol} / \mathrm{L})$ & $3.56(2-5.6)$ & $3.25(1.5-5.5)$ & 0.865 & $3.82(2.4-5.9)$ & $3.65(1.6-5.7)$ & 0.557 \\
\hline $\begin{array}{l}\text { Triglycerides } \\
(\mathrm{mmol} / \mathrm{L})\end{array}$ & $1.675(0.7-7.3)$ & $2.13(0.8-6.3)$ & 0.149 & $1.42(0.9-3.6)$ & $2.02(1.1-7)$ & 0.209 \\
\hline PTH $(\mathrm{pg} / \mathrm{mL})$ & $109(36.5-379)$ & $113(33.9-894)$ & 0.924 & $43(13.6-162)$ & $126(21-735)$ & 0.009 \\
\hline
\end{tabular}

All data reported as median (range from minimum to maximum); p calculated using Mann-Whitney test; IIEF-5 = International Index of Erectile Function questionnaire; RRT = renal replacement therapy; TX = renal transplantation; BMI = body mass index; RBC = red blood cell; $\mathrm{Hgb}=$ hemoglobin; hs-CRP = high-sensitivity C-reactive protein; $\mathrm{HDL}=$ high-density lipoprotein; $\mathrm{LDL}=$ low-density lipoprotein; $\mathrm{PTH}=$ parathyroid hormone

Vitamin D deficiency has already been linked to classic CVD risk factors, such as inflammation in vascular endothelium, DM and hypertension, which all are shared ED risk factors causing $\mathrm{END}^{8}$. Recently, it was demonstrated that a significant proportion of ED patients had VDD, again with END as a plausible underlying pathologic mechanism ${ }^{9}$. CKD, an independent risk factor for CVD, with its concomitant metabolic diseases and END is a particularly good setting for ED to occur ${ }^{10}$, a finding supported by observational studies. In addition, CKD patients are predisposed to ED because of hormonal abnormalities, anemia and usage of multiple drugs such as beta blockers and some diuretics, which can worsen the erectile function. Furthermore, even after successful kidney TX, where improvement of erectile function is expected ${ }^{14}$, there are vascular factors to be taken into consideration that may have an impact on postoperative ED occurrence.
End-to-end arterial anastomosis with the internal iliac artery has previously been shown to reduce cavernosal arterial flow ${ }^{15}$, but recently similar effect was also found for end-to-side external iliac artery anastomosis ${ }^{16}$.

Vitamin D deficiency in CKD population has been extensively studied but never linked to ED. There are numerous reports of high VDD prevalence among kidney transplant recipients ${ }^{17-19}$, but the high-level evidence for its exact impact on major outcomes (glomerular filtration rate, acute rejection, chronic allograft nephropathy, proteinuria and graft loss) is still lacking, although a systematic review is underway ${ }^{20}$. Apart from traditional VDD risk factors ${ }^{5}$ (age, race, female gender, geographic latitude, altitude, time of day, winter season, air pollution, and obesity) and preventive reduced sun exposure in transplant recipients, there is also evidence that $25(\mathrm{OH}) \mathrm{D}$ levels are inversely associated with the usage of calcineurin inhibitors as im- 
munosuppressants ${ }^{17}$. In a recent study, Yildirim et al. ${ }^{21}$ found significantly lower vitamin D levels in renal transplant recipients with END compared to patients with normal endothelial function, and conclude that VDD is associated with END in that population. To our knowledge, the only reference to VDD impact on $\mathrm{ED}$ in CKD patients is found in an article published in 1977, reporting on improvement of erectile function in dialysis patients after treatment with vitamin D supplements ${ }^{11}$.

In our study, we found similar rates of VDD as in previously published studies ${ }^{17-19}$. On the summer and winter measurements of $25(\mathrm{OH}) \mathrm{D}, \mathrm{VDD}$ was present in $42.5 \%$ and $62.5 \%$ of patients, insufficiency in $30 \%$ and $17.5 \%$, while $27.5 \%$ and $20 \%$ of patients were vitamin D sufficient. As expected, the finding of a higher percent of VDD in winter season was due to seasonal variations in cutaneous production of vitamin $\mathrm{D}$. The Croatia's geographic latitude is between $42^{\circ}$ i $46^{\circ}$ north of the equator, where there is little if any vitamin $\mathrm{D}$ produced in skin during winter months, regardless of the amount of sun exposure ${ }^{5,22}$. However, the distribution of 25(OH)D levels did not differ between the two measurements (summer median of $22.05 \mathrm{ng} / \mathrm{mL}$ versus winter median of $19.05 \mathrm{ng} / \mathrm{mL} ; \mathrm{p}=0.737$ ). This could be explained by general sun avoiding in kidney transplant patients, according to their nephrologist recommendation or vitamin $\mathrm{D}$ supplementation in some of them. The finding of lower red blood cell and hemoglobin concentrations in VDD patients is in line with the published data on VDD association with anemia in CKD patients. Although the exact mechanism is unknown, VDD may impair erythropoiesis via immune activation within the bone marrow ${ }^{23}$.

Out of 40 study patients, only 10 (25\%) had no ED (ED 0 group), 20 patients had mild (ED 1) and seven patients mild to moderate ED (ED 2), while three patients had severe ED (ED 4 group). The high presence of ED among our renal transplant recipients is in line with earlier reports of $42 \%$ to $78 \%$ prevalence in this population $^{12,24-27}$. The levels of $25(\mathrm{OH}) \mathrm{D}$ and $\mathrm{PTH}$, as well as other study parameters on both measurements did not differ among ED groups. We then compared ED 0 and other ED categories (Table 2) and found no difference in $25(\mathrm{OH}) \mathrm{D}$ levels between patients with and without ED. Time on RRT before TX and graft duration until analysis were significantly shorter in non-ED group, but on logistic regression the results proved to be nonsignificant. The association of both shorter RRT time before TX and recently performed TX with better erectile function could be explained by less time on pre-transplant dialysis and better renal function in the early postoperative months.

On stratifying study patients according to $25(\mathrm{OH})$ D cutoff of $20 \mathrm{ng} / \mathrm{mL}$, we found the distribution of IIEF-5 score to be similar and again nonsignificant for both measurements, which recapitulated our finding of no vitamin $\mathrm{D}$ status linkage to $\mathrm{ED}$ in the current study. The explanation for this could be based on the multifactorial ED etiology in a population already predisposed to ED, so that pinpointing VDD as an exclusive $\mathrm{ED}$ cause is somewhat improbable. Also, radioimmunoassay was a method used for 25(OH)D measurement and with liquid chromatography-tandem mass spectrometry (LC-MS/MS), which is the gold standard for evaluating $25(\mathrm{OH}) \mathrm{D}$ status ${ }^{5}$ but currently unavailable to us, reassessment with a larger number of study subjects is needed. As our research was a crosssectional observational study, future interventional studies with vitamin D supplementation could presumably shed more light on its impact on ED occurrence and severity.

In conclusion, we found no association between vitamin $\mathrm{D}$ serum concentration and the presence and severity of ED in renal transplant recipients. To date, there are no similar published data linking VDD and $\mathrm{ED}$ in $\mathrm{CKD}$ and renal transplant populations. High rates of VDD and ED found in this population should not be considered as a quality-of-life matter only because of the possible and/or proven effects on patient general health via END and CVD.

\section{References}

1. Akkus E, Kadioglu A, Esen A, Doran S, Ergen A, Anafarta K, et al. Prevalence and correlates of erectile dysfunction in Turkey: a population-based study. Eur Urol. 2002;41:298-304, https://doi.org/10.1016/S0302-2838(02)00027-1.

2. Chew KK, Earle CM, Stuckey BG, Jamrozik K, Keogh EJ. Erectile dysfunction in general medicine practice: prevalence and clinical correlates. Int J Impot Res. 2000;12:41-5.

3. Feldman HA, Goldstein I, Hatzichristou DG, Krane RJ, McKinlay JB. Impotence and its medical and psychosocial correlates: results of the Massachusetts Male Aging Study. J Urol. 1994;151:54-61.

4. Dong JY, Zhang YH, Qin LQ. Erectile dysfunction and risk of cardiovascular disease: meta-analysis of prospective cohort 
studies. J Am Coll Cardiol. 2011;58:1378-85, https://doi. org/10.1016/j.jacc.2011.06.024.

5. Hossein-Nezhad A, Holick MF. Vitamin D for health: a global perspective. Mayo Clin Proc. 2013;88:720-55, https://doi. org/10.1016/j.mayocp.2013.05.011.

6. Hossein-Nezhad A, Spira A, Holick MF. Influence of vitamin $\mathrm{D}$ status and vitamin D3 supplementation on genome wide expression of white blood cells: a randomized double-blind clinical trial. PLoS One. 2013;8:e58725, https://doi.org/10.1371/ journal.pone.0058725.

7. Holick MF, Binkley NC, Bischoff-Ferrari HA, Gordon CM, Hanley DA, Heaney RP, et al. Evaluation, treatment, and prevention of vitamin D deficiency: an Endocrine Society clinical practice guideline. J Clin Endocrinol Metab. 2011;96:1911-30, https://doi.org/10.1210/jc.2011-0385.

8. Sorenson M, Grant WB. Does vitamin D deficiency contribute to erectile dysfunction? Dermatoendocrinology. 2012;4:12836, https://doi.org/10.4161/derm.20361.

9. Barassi A, Pezzilli R, Colpi GM, Corsi Romanelli MM, Melzi d'Eril GV. Vitamin D and erectile dysfunction. J Sex Med. 2014;11:2792-800, https://doi.org/10.1111/jsm.12661.

10. Suzuki E, Nishimatsu H, Oba S, Takahashi M, Homma Y. Chronic kidney disease and erectile dysfunction. World J Nephrol. 2014;3:220-9, https://doi.org/10.5527/wjn.v3.i4.220.

11. Massry SG, Goldstein DA, Procci WR, Kletzky OA. Impotence in patients with uremia: a possible role for parathyroid hormone. Nephron. 1977;19:305-10.

12. Wang WG, Li P, Wang YS, Wang G, Wang YT, Zhou HL. The effect of erectile dysfunction on quality of life in male kidney transplant recipients. Pak J Med Sci. 2014;30:361-5.

13. Rosen RC, Cappelleri JC, Smith MD, Lipsky J, Peña BM. Development and evaluation of an abridged, 5-item version of the International Index of Erectile Function (IIEF-5) as a diagnostic tool for erectile dysfunction. Int J Impot Res. 1999;11:31926, https://doi.org/10.1038/sj.ijir.3900472.

14. Nassir A. Sexual function in male patients undergoing treatment for renal failure: a prospective view. J Sex Med. 2009;6:3407-14, https://doi.org/10.1111/j.1743-6109.2009.01411.x.

15. El-Bahnasawy MS, El-Assmy A, Dawood A, Abobieh E, Dein $\mathrm{BA}, \mathrm{El}-\mathrm{Din} \mathrm{AB}$, et al. Effect of the use of internal iliac artery for renal transplantation on penile vascularity and erectile function: a prospective study. J Urol. 2004;172:2335-9, https://doi. org/10.1097/01.ju.0000144403.03734.11.

16. Gontero P, Oderda M, Filippini C, Fontana F, Lazzarich E, Stratta $\mathrm{P}$, et al. Does kidney transplantation onto the external iliac artery affect the haemodynamic parameters of the cavernosal arteries? Asian J Androl. 2012;14:621-5, https://doi. org/10.1038/aja.2011.115.
17. Filipov JJ, Zlatkov BK, Dimitrov EP, Svinarov D. Relationship between vitamin $\mathrm{D}$ status and immunosuppressive therapy in kidney transplant recipients. Biotechnol Biotechnol Equip. 2015; 29:331-5, https://doi.org/10.1080/13102818.2014.995415.

18. Aggarwal M, Sahoo SP, Bhandari HS, Kriplani J, Mithal A. Prevalence of vitamin D deficiency in post renal transplant patients. Indian J Endocrinol Metab. 2012;16:274-6, https://doi. org/10.4103/2230-8210.93751.

19. Stavroulopoulos A, Cassidy MJ, Porter CJ, Hosking DJ, Roe SD. Vitamin D status in renal transplant recipients. Am J Transplant. 2007;7:2546-52, https://doi.org/10.1111/j.1600$-6143.2007 .01978 . x$.

20. Hesketh CC, Knoll GA, Molnar AO, Tsampalieros A, Zimmerman DL. Vitamin D and kidney transplant outcomes: a protocol for a systematic review and meta-analysis. Syst Rev. 2014;3:64, https://doi.org/10.1186/2046-4053-3-64.

21. Yildirim T, Yilmaz R, Altindal M, Turkmen E, Arici M, Altun $\mathrm{B}$, et al. Endothelial dysfunction in renal transplant recipients: role of vitamin D and fibroblast growth factor-23. Transplant Proc. 2015;47:343-7, https://doi.org/10.1016/j.transproceed. 2014.12.023.

22. Laktašić-Žerjavić N, Koršić M, Crnčević-Orlić Z, Anić B. Vitamin D: vitamin from the past and hormone of the future. Lijec Vjesn. 2011;133:194-204. (in Croatian)

23. Santoro D, Caccamo D, Lucisano S, Buemi M, Sebekova K, Teta D, et al. Interplay of vitamin D, erythropoiesis, and the rennin-angiotensin system. Biomed Res Int.2015;2015:145828, https://doi.org/10.1155/2015/145828.

24. Espinoza R, Gracida C, Cancino J, Ibarra A. Prevalence of erectile dysfunction in kidney transplant recipients. Transplant Proc. 2006;38:916-7, https://doi.org/10.1016/j.transproceed.2006.02.045.

25. Teng LC, Wang CX, Chen L. Improved erectile function and sex hormone profiles in male Chinese recipients of kidney transplantation. Clin Transplant. 2011;25:265-9, https://doi. org/10.1111/j.1399-0012.2010.01237.x.

26. Mekki MO, El Hassan KA, El Mahdi EM, Haroun HH, Mohammed MA, Khamis KH, et al. Prevalence and associated risk factors of male erectile dysfunction among patients on hemodialysis and kidney transplant recipients: a cross-sectional survey from Sudan. Saudi J Kidney Dis Transpl. 2013;24:500-6, https: //doi.org/10.4103/1319-2442.111023.

27. Lasaponara F, Paradiso M, Milan MG, Morabito F, Sedigh O, Graziano ME, et al. Erectile dysfunction after kidney transplantation: our 22 years of experience. Transplant Proc. 2004;36: 502-4, https://doi.org/10.1016/j.transproceed.2004.02.014. 


\title{
Sažetak
}

\section{NEPOVEZANOST SERUMSKOG STATUSA VITAMINA D I EREKTILNE DISFUNKCIJE U PRIMATELJA BUBREŽNOG PRESATKA}

\author{
B. Sudarević, I. Begić, D. Šimunovic, H. Kuveždić, V. Šerić i L. Zibar
}

Erektilna disfunkcija (ED) je poremećaj visoke učestalosti u bolesnika nakon transplantacije bubrega. Deficijencija vitamina $\mathrm{D}$ (VDD) je već ranije povezana s nekoliko rizičnih čimbenika za ED, ali je tek nedavno dovedena u izravnu vezu s ED. $\mathrm{U}$ predmetnom smo istraživanju ispitali je li serumska vrijednost vitamina $\mathrm{D}$ povezana s prisutnošću i jačinom izraženosti ED u 40 muških ispitanika u kojih je kadaverična transplantacija bubrega (TX) učinjena od 2001. do 2013. godine. Serumsko uzorkovanje je učinjeno u dva sezonski različita razdoblja, uz mjerenje koncentracije vitamina $D$ radioimuno testom. Upitnik International Index of Erectile Function (IIEF-5) korišten je za stratifikaciju bolesnika s obzirom na jačinu ED. Pronašli smo usporedivu učestalost $\mathrm{ED}(75 \%)$ i $\mathrm{VDD}(42,5 \%-62,5 \%)$ kao u dosad objavljenim istraživanjima. Ni u jednom mjerenju nije utvrđena razlika u serumskim vrijednostima $25(\mathrm{OH}) \mathrm{D}$ između ispitanika s ED i bez nje ( $\mathrm{p}=0,656$ i $\mathrm{p}=0,914)$, kao ni među ispitanicima s različito izraženom ED. Trajanje bubrežne nadomjesne terapije (RRT) prije TX i "trajanje" transplantata do analize bilo je duže za ispitanike s $\mathrm{ED}(\mathrm{p}=0,022$ odnosno $\mathrm{p}=0,05)$, no samo u univarijatnoj analizi. Zaključno, nismo pronašli povezanost između serumske razine $25(\mathrm{OH}) \mathrm{D}$ i prisutnosti te jačine izraženosti ED. Prema našim spoznajama, dosad nema sličnih objavljenih rezultata za navedenu populaciju bolesnika.

Ključne riječi: Vitamin D, nedostatak; Erektilna disfunkcija; Endotel, vaskularni; Bubrežna insuficijencija, kronična; Bubreg; transplantacija; Hrvatska 